\title{
Urbanisation and Development in West Africa: Challenges and Policy Implications.
}

Eugene J. Aniah.

University of Calabar, Calabar - Nigeria

\section{Abstract}

The West African sub-region is experiencing a sprout in urbanisation. Although it is adjudged the second slowest growing region in Africa, its rate of urban growth is still quite high by world standards. In 1960, the urban component of the region was estimated to be only 19.6 percent, but in 2000 it had grown to 40.7 percent (UNCHS, 1996). Is this fast pace of urban growth synonymous with socio-economic development in the region as is seen elsewhere? Unfortunately, this is not so. Rather, urban conditions and infrastructure remain parlous with abject poverty, illegal and ghetto settlements, poor communication and accessibility; ineffectual electricity water and sanitation refuse disposal and housing services. There are peculiarities and factors that drive the urbanisation process. This contribution tries to find meaning for the seemingly intractable developmental nexus vis-à-vis rapid urbanisation within the sub region. Some policy options are proffered as sustainable alternatives to obviate this anomalous state of affairs.

\section{Introduction}

Urban growth within West Africa has been steady but not astronomical. In 1970 the percentage of the total population living in urban areas was $19.6 \%$, but by 2000 it had increased fairly significantly to $40.7 \%$ (Table 1). By 2025 , it is estimated that $58.9 \%$ of West Africans will be living in urban areas. Compared to other regions of Africa, its rate of urbanisation only supersedes that of East Africa. While Southern Africa remains the most highly urbanised closely followed by Northern Africa with $49.9 \%$ and Middle Africa with $47.6 \%$ in 2000 . Other estimates project that the continent's urban population will double every 12 years (Polese, 1997).

Each country in West Africa portrays a unique system of urban development with its distinct features and characteristics within the spatial national urban system ranging from the very large and complex (Nigeria), to the very tiny and small in population and area extent (Equatorial Guinea, Gambia, and Sao Tome and Principe).

Nigeria, with the largest population in the sub-region also has the greatest number of urban centres, many more millionaire cities and the largest spatial network of towns and cities (Table 2) than any other region in 
the sub-region. The population of Lagos grew quite astronomically at an average rate of 5.6 per cent per annum over and above the national average of 3 per cent for the period 1975-2000 (Polese, 1997). At the other end of the spectrum, due to their population size, more than half of the countries of the sub-region: Burkina Faso, Cape Verde, Chad, Equatorial Guinea, Gambia, Guinea Bissau, Liberia, Mauritania, Sao Tome and Principe, Sierra Leone and Togo have five or less urban centres with population of 50,000 and above (Table 2).

Table 1: Sub-Regional Urban Growth in Africa: Percentage of total population living in urban areas

\begin{tabular}{|l|c|c|c|}
\hline Sub-Region & 1970 & 2000 & 2025 \\
\hline East Africa & 10.3 & 30.0 & 48.0 \\
Middle Africa & 24.0 & 47.6 & 64.7 \\
Northern Africa & 36.0 & 49.9 & 65.3 \\
Southern Africa & 44.0 & 61.7 & 74.2 \\
Western Africa & 19.6 & 40.7 & 58.9 \\
\hline
\end{tabular}

Sources: United Nations, 1988, 1989a; UNCHS, 1996.

Table 2: Urbanisation in West Africa.

\begin{tabular}{|c|c|c|c|c|}
\hline Country & $\begin{array}{l}\text { Total pop } \\
\text { (m) }\end{array}$ & $\begin{array}{c}\text { \% urban } \\
(2000\end{array}$ & $\begin{array}{c}\text { Pop. of } \\
\text { national } \\
\text { capital city }\end{array}$ & $\begin{array}{c}\text { Cities with } \\
\text { pop of } 50 \text {, } \\
000+\end{array}$ \\
\hline Benin & 6.7 & 42 & $\begin{array}{l}221,891 \\
(2002)\end{array}$ & 10 \\
\hline Burkina Faso & 11.3 & 19 & $\begin{array}{r}709,736 \\
(1996)\end{array}$ & 5 \\
\hline Cape Verde & 0.4 & 44 & $\begin{array}{l}95,200 \\
(2000)\end{array}$ & 2 \\
\hline Chad & 9.2 & 44 & $\begin{array}{r}530,965 \\
(1993)\end{array}$ & 5 \\
\hline Cote' D' Iv. & 15.3 & 46 & $\begin{array}{r}2,877,948 \\
(1998)\end{array}$ & 20 \\
\hline Eq. Guinea & 0.4 & 48 & $\begin{array}{l}92,900 \\
(2003)\end{array}$ & 2 \\
\hline Gambia & 1.2 & 37 & 34,828 & 11 \\
\hline
\end{tabular}




\begin{tabular}{|c|c|c|c|c|}
\hline & & & $\begin{array}{l}(2003) \\
\end{array}$ & \\
\hline Ghana & 18.8 & 37 & $\begin{array}{r}1,038,000 \\
(1990)\end{array}$ & 11 \\
\hline Guinea & 7.5 & 33 & $\begin{array}{r}9,030,200 \\
(2003)\end{array}$ & 7 \\
\hline Guinea Bissau & 1.3 & 24 & $\begin{array}{r}203,000 \\
(1990)\end{array}$ & 1 \\
\hline $\begin{array}{l}\text { Liberia } \\
\text { Mali }\end{array}$ & 2.8 & 45 & - & 1 \\
\hline & 10.1 & 23 & $\begin{array}{r}203,000 \\
(1990)\end{array}$ & 8 \\
\hline Mauritania & 2.5 & 58 & $\begin{array}{r}558,195 \\
(2000)\end{array}$ & 3 \\
\hline Niger & 10.7 & 25 & $\begin{array}{r}674,950 \\
(2001)\end{array}$ & 6 \\
\hline Nigeria & 130 & 44 & $\begin{array}{r}371,674 \\
(1991)\end{array}$ & 156 \\
\hline $\begin{array}{l}\text { Sao Tome } \\
\text { and Principe }\end{array}$ & 0.13 & 66 & $\begin{array}{l}51,886 \\
(2001)\end{array}$ & 1 \\
\hline Senegal & 10.1 & 47 & $\begin{array}{r}1,982,093 \\
(2002)\end{array}$ & 12 \\
\hline Sierra Leone & 3.5 & 37 & $\begin{array}{r}1,982,093 \\
(2002)\end{array}$ & 4 \\
\hline $10 \mathrm{~g}$ & 5.4 & 33 & $\begin{array}{r}732,000 \\
(2001)\end{array}$ & 2 \\
\hline
\end{tabular}

Sources: UNCHS, 1996, UNDP (2000) Stren, R; White, R. and Whitney, J. (1992). Thomas Brinkhoff, City Population, 2004.

\section{Conceptualisation of West African urbanisation.}

Many concepts exist to portray the nature of city growth and expansion or urbanisation generally (Todaro 1986; Chadwick 1987; Mabogunje 1970; Odum 1985; Stillwell 1975; etc.), but the peculiar circumstances normally associated with African urbanisation have also been elaborated (Peil, 1986; Peil and Sada 1984; Stren et al, 1992; Satterthwaite, 1997; Simon, 1992; Gugler, 1996, 1997; Adepoju, 1988; Gilbert, 1993; Mabogunje, 1990; Njor, 2003). However, Mabogunje's (1970) conceptualisation (systems model, Fig. 1) seems the most apt in modelling West African urbanisation. He 
posits that rural-urban migration, as a major component of urbanisation, is influenced by several environmental factors such as the social development in health and education; economic conditions such as wages, prices, consumer preferences, the degree of commercialisation and industrial development; technological advancement in transportation, communication and mechanization; and government policies that impinge on agricultural practices, marketing organisation and population movement within each country or region. In addition the migrant is influenced by the rural control sub-system, the rural adjustment mechanism and the urban control subsystem, while the migration channels are influenced either positively or negatively by feedback.

Chadwick (1987) also highlights the adequacy of the general systems theory as a framework in modelling urbanisation phenomena within urbanizing regional systems. These include:

i) The exponential or logistic growth of population (and its decay), and of urbanized population, of population/distance effects in cities and in the demographic transition.

ii) Competition and exclusion, as demonstrating relative feedback patterns eg. hotelling, and rental/accessibility/land value patterns.

iii) The rank size rule, and other Pareto distributions as well as the allometric law.

iv) Hierarchical order relationships as in central-places and other patterns.

v) The general operation of feedback; of conditions of homeostasis and morphogenesis; of conditions of stability and complexity; of threshold situations and homeostatic plateaux.

vi) The phenomenon of equifinality, shown by urban systems, for example the growth of very large cities through migration at various historical times, or the urban/rural ecological relationships at various times and in various civilizations and cultures.

It is quite evident that the extant scenario within West African is in addition to the above imbued with inherent peculiarities and features within the nation states that may or may not be distinctly different from one another.

\section{Major causes of movement to West African cities.}

Much has been said and proffered about the causal explanations for urbanward migration. The following appear to be the main reason: rural underdevelopment; need fro education; urban bias; and political and administrative changes. 


\section{Rural underdevelopment}

This remains a major push for migration into cities. The poverty in rural areas is far greater than that exiting in the urban areas (World Bank, 2002, Population Reports, 2003). With most residents engaged in rudimentary agricultural production, output is limited and seasonal. Most women and children spend several hours of the day in search of wood fuel and water. Existence is basically at the subsistence level, and the basic infrastructure and services such as electricity, potable water, schools and accessibility are either in deplorable conditions, unavailable or scarce. Any decent level of living, therefore, can only be attained in the urban centres, leading to continuous and unrestrained movement from the rural hinterland to the towns and cities.

\section{The need for education}

Another causal factor for migration into West African cities is the need for education (Peil and Sada, 1984, Mabogunje, 1989, Potter and Lioyd-Evans, 1998). Other than primary schools, most secondary and tertiary institutions are located in the cities. In Nigeria for instance, all the 59 universities are located in towns and cities. Since education uplifts a migrant's status, both socially and economically, (job prospects are higher), they opt to be educated even when it is often difficult. On attainment of better education most migrants can find formal jobs and get lifted out of the informal sector.

\section{Urban bias}

A major constraint to equitable regional development within the sub-region is urban bias (Roberts, 1978, 1995; Lipton, 1977, 1982). This has since independence meant that development remains skewed in favour of the urban centres, with regional inequalities in the national spatial system. As this happens more people are compelled to move to where there is hope of a better livelihood. As has been contended by several other researchers, 'urban bias' policies "translate into a higher standard of living for urban citizens" (Bradshaw and Noornan, 1997:8), and rural dwellers in West Africa remain virtual outsiders in the gains of development.

\section{Political and administrative changes}

Political development and power shifts since the independence has resulted in several political and administrative restructuring into states, provinces, prefectures, counties, local government areas etc. In Nigeria, for instance, states have increased from 12 in 1967 to 36 in 1996, resulting in new headquarters and administrative centres, leading to more migration from the surrounding countryside into them. 


\section{The features of West African urbanisation: a typology.}

Mabogunje (1968) has attempted a categorization of African cities and posits that they "are less differentiated by function and area" to be intrinsically based on the interaction between two histories of pre-colonial urbanisation and a colonial quasi-industrial urbanisation. The typology of West African urbanisation shows clearly the following features: primate cities, port city capitals, secondary cities and new capital cities.

\section{Primate Cities:}

Nearly all the nations within the sub-region have a great proportion of the urban population resident in the national capital. However, the countries that have attained a primate status (more than $25 \%$ of total urban population resident in national capital) are Benin, Chad, Cote d'Ivoire, Gambia, Ghana, G. Bissau, Mali, Mauritania, Niger, Senegal, Sierra Leone and Togo (Table 3). The status of Lagos, Nigeria is rather unique. It was until 1996 the capital city of Nigeria, but at the moment its population is more than 5 million residents, while estimates by the UNDP (2003) have it that including greater Lagos, the population is more than 13 million, which is over a quarter of the total urban population of Nigeria. It also has over $65 \%$ of all industrial establishments in the whole country.

Table 3: Primacy in West Africa: Some apt Indicators.

\begin{tabular}{|l|r|r|r|}
\hline Country & Total population & $\begin{array}{r}\text { Population of } \\
\text { urban cities }\end{array}$ & $\begin{array}{c}\text { \% of urban pop } \\
\text { \% of urban pop }\end{array}$ \\
\hline Benin & $6,752,569$ & 658,572 & 26.3 \\
Cape Verde & 434,625 & 95,200 & - \\
Chad & $9,253,500$ & 530,965 & 29.5 \\
Cote d'Ivoire & $15,366,672$ & $2,877,948$ & 40.5 \\
Gambia & $1,364,507$ & $1,364,507$ & 80.6 \\
Ghana & $18,845,265$ & $1,038,000$ & 14.6 \\
G. Bissau & $1,360,800$ & 203,000 & 67.7 \\
Mali & $10,179,170$ & $10,179,170$ & 38.0 \\
Mauritania & $2,508,159$ & 558,195 & 37.2 \\
Niger & $10,790,352$ & 674,950 & 32.1 \\
Senegal & $10,127,809$ & $1,983,093$ & 46.1 \\
Sierra Leone & $3,515,812$ & 469,776 & 26.1 \\
Togo + & $5,429,300$ & 375,499 & 25.0 \\
\end{tabular}

Various Sources 
Within the region many cities have hit a million and continue to be significant centres of economic and administrative organisation in their respective countries. Nigeria has the greatest number of these, with Lagos, Ibadan, Oshogbo, Ilorin and Benin representing the highly urbanised south west Kano, an expansive settlement, and the most important economic and cultural nerve centre, is the largest metropolis in the north. The colonial and administrative heritage of Kaduna has made it another important centre, as well as Maiduguri (the epicentre of the Kanuri kingdom), Zaria (an emirate and a famous University town) and Jos (an important tin mining and tourism centre). In the south and south eastern Nigeria urban centres that are above the million mark include Enugu (the defunct capital of former eastern Nigeria and now an important coal mining and administrative centre), Port Harcourt (the headquarters of Nigeria's petrochemical industry) and Aba (a highly enterprising business centre).

Table 4: Millionaire Cities of West Africa.

\begin{tabular}{|c|c|c|}
\hline Country & City & Population \\
\hline Cote d'Ivoire & Abidjan & 2,877,948 (1998 \\
\hline Ghana & Accra & $1,038,000(1990)$ \\
\hline Guinea & Conakry & $1,092,936(1996)$ \\
\hline Mali & Bamako & $1,016,167(1998$ \\
\hline \multirow[t]{4}{*}{ Nigeria } & Lagos & $5,195,247(1991$ \\
\hline & Kano & $2,166,554$ \\
\hline & Ibadan & $1,835,300$ \\
\hline & $\begin{array}{l}\text { Kaduna, Benin, Port } \\
\text { Harcourt, Maiduguri, } \\
\text { Zaria, Ilorin, Jos and } \\
\text { Aba)* }\end{array}$ & $\begin{array}{l}\text { Also estimated at over } 1 \\
\text { million in } 2002\end{array}$ \\
\hline Senegal & Dakar & $1,983,093(2002)$ \\
\hline
\end{tabular}

Sources: National Population Commission, Nigeria, (1996, 2002).

Thomas Brinkhoff, www.CityPopulation, 2004.

\section{Port City Capitals}

Due to historical circumstances most West African countries have access to the sea, and tended to develop inwards and as a result, there are large settlements in the ports and other proximous centres. Most of the national 
capital cities therefore are port towns. These include: Porto Novo (Benin), Malabo (Equatorial Guinea), Monrovia (Liberia), Lome (Togo), Freetown (Sierra Leone), Dakar (Senegal), Sao Tome (Sao Tome), Abidjan (Cote d'Ivoire), Nouakchott (Mauritania), Bissau (Guinea Bissau), Conakry (Guinea) Accra (Ghana) and Banjul (Gambia).

\section{Growth and Proportion of Secondary cities}

Secondary cities (or medium sized cities, usually accommodating between 200-350,000 inhabitants or more, but not exceeding 1000,000 inhabitants) are a major component of West African urbanisation and the urban maturation process. Although much of the urbanisation in many countries is "single city based" a lot of the urban population is normally found in secondary cities. Hierarchically, both in functionality, political prominence, industrialization and amenities provision, they are placed second to the dominant capital city which invariably is also the primate city in most national city systems within the region.

Nigeria has the widest spread and greatest number of secondary cities in West Africa. Due to its political structure of 36 states, each state capital city is invariably a secondary city while Lagos is the primate city with over 12 million inhabitants. It is also the centre of commerce with over 60 of all industrial establishments in the country. Abuja, the new capital city is rightfully a secondary city through its newness, and with a population of about 300,000 .

The advantages of secondary cities are various. Rondinelli (1983) argues that secondary cities provide (in both concrete and spatial terms) "a de-concentrated, articulated and integrated system of cities." According to him, secondary cities provide the following advantages within a regional system of cities.

a) Pressures on the largest cities are relieved in terms of problems and amenity provision in housing, transportation, pollution, employment and poverty.

b) Regional inequalities are reduced through the spread of benefits of urbanisation through the secondary cities.

c) Rural economies are stimulated through the provision of services, facilities and markets for agricultural products and the absorption of surplus labour as labour efficiency is achieved in agricultural production.

d) There is increased and decentralized regional administrative capacity.

e) Due to interaction and flow of resources, poverty is alleviated in the intermediate cities. 
Either through the generative or parasitic perspective, Rondinelli further highlights that the extent to which secondary cities influence regional development is dependent on the following attributes:

i) Local leaders identify their success with that of their city and its region.

ii) ii)Local leaders invest in their city

iii) iii)They are innovative.

iv) They are aggressive.

v) The national government supports the internal growth of the city and its region

vi) The economic activities within the city are linked to its hinterland through mutually beneficial processes of exchange.

vii) The economic activities within the city are linked to each other to generate multiplier effects.

viii) Economic activities within the city are organised to generate income for local residents and promote internal demand.

ix) The public and private sectors cooperate to promote economic activities that generate widespread participation and distribution of benefits.

$\mathrm{x}$ The willingness of the city's leaders to promote and encourage social and behavioural changes responsive to the city's residents.

New capital cities.

The development of new capital cities (Table 5.1) in some countries in SubSaharan Africa has tended to increase new settlement development and urban-ward migration hence urbanisation. Some of these cities have been created merely for political reasons (Dodoma, Tanzania), as well as for enhanced national cohesion (Abuja, Nigeria).

Table 5: New Capital Cities of West Africa

\begin{tabular}{|l|l|l|}
\hline Country & New capital & Old capital \\
\hline $\begin{array}{l}\text { Nigeria } \\
\text { Cote d'Ivoire }\end{array}$ & $\begin{array}{l}\text { Abuja } \\
\text { Yamoussoukro }\end{array}$ & $\begin{array}{l}\text { Lagos } \\
\text { Abidjan }\end{array}$ \\
\hline Country & New name & Former name \\
\hline $\begin{array}{l}\text { Gambia } \\
\text { Chad }\end{array}$ & Banjul & Bathurst \\
N'Djamena & Fort Lamy \\
\hline
\end{tabular}

Source: Stock, R. (1995) Africa South of the Sahara. Guillford Press, 19. 


\section{Urbanisation and development: growth without development?}

As enunciated by Gore (1984:149/50) "Urbanisation is not in itself bad. The problem is the spatial and hierarchical distribution of the population. In the end, developing countries need to bridge 'the void between the ubiquitous villages and parasitic great cities' by building a 'proper' Loschian hierarchy of urban centres which ranges from small towns to intermediate cities and national metropolis." This primarily is the problem with West African urbanisation, and due to the apparent maldistribution and malfunctionality of the urban centres development is barely evident. In essence there has been growth in urbanisation but not development.

It would seem that far from the predicament of people wishing to live mainly in towns, the question is whether the urban areas require them. An analysis of the level of poverty (urban-rural differentials), infant mortality, life expectancy at birth, literacy level, and the incidence of HIV/AIDS among the countries of the region shows a deplorable state of affairs (Table $6)$.

\section{The utterly vulnerable}

In this category are Niger, Chad, Liberia, Guinea, Guinea Bissau, Mauritania, Benin, Burkina Faso, Sierra Leone and Sao Tome. Due to the harsh political, socio-economic and environmental conditions that exist in these countries development has been quite elusive, even with rising levels of urbanisation. Liberia and Sierra Leone have remained under civil strife for several years with catastrophic consequences. Niger, Chad and Mauritania lie within or at the fringe of the Sahara desert with drought conditions that result in food shortages and famine. In 2004 the FAO (Food and Agricultural Organisation of the United Nations) warned that drought and food shortages were imminent due to the influence of locusts that were devastating Niger in particular. The FAO further estimated that more than 2.5 million people and 32,000 children would be affected by acute food shortages. 
Table 6: Other Development Indices for West Africa (2004).

\begin{tabular}{|c|c|c|c|c|c|c|c|c|c|}
\hline \multirow[t]{2}{*}{ Country } & \multirow[t]{2}{*}{$\begin{array}{l}\text { Poverty } \\
\text { U/R }\end{array}$} & \multicolumn{3}{|c|}{$\begin{array}{c}\text { Infant mortality } \\
\text { Rate }\end{array}$} & \multirow{2}{*}{$\begin{array}{c}\text { Life Exp. } \\
\text { at birth } \\
(\mathrm{m} / \mathrm{f})\end{array}$} & \multirow[t]{2}{*}{$\begin{array}{c}\text { GDP } \\
\$\end{array}$} & \multirow[t]{2}{*}{$\begin{array}{l}\text { FDI } \\
\$ \mathrm{~m}\end{array}$} & \multirow[t]{2}{*}{ Literacy } & \multirow[t]{2}{*}{$\begin{array}{l}\text { Ext. Debt. } \\
\text { (USD) }\end{array}$} \\
\hline & & 1980 & 1990 & 1997 & & & & & \\
\hline Benin & 33 & 107 & 90 & 80 & $48 / 53$ & 440 & 51 & 39.8 & $1,308.1$ \\
\hline Burkina Faso & - & 66 & 50 & 39 & $45 / 46$ & 300 & 11 & 12.8 & 221.8 \\
\hline Cape Verde & - & 143 & 123 & 111 & $67 / 73$ & 1490 & 14 & 75.7 & 887.7 \\
\hline Chad & $63 / 67$ & 105 & 91 & 83 & $44 / 46$ & & & & $17,680.0$ \\
\hline $\begin{array}{l}\text { Cote d' } \\
\text { Ivoire }\end{array}$ & - & 137 & 117 & 103 & $41 / 41$ & 660 & 389 & 49.7 & $28,774.0$ \\
\hline Eq. Guinea & - & 154 & 132 & 118 & $48 / 50$ & & & & 439.3 \\
\hline Gambia & 64 & 157 & 134 & 120 & $53 / 55$ & 310 & 60 & 37.8 & $3,392.8$ \\
\hline Ghana & $27 / 34$ & 163 & 141 & 128 & $56 / 59$ & 320 & 137 & 73.8 & 889.0 \\
\hline Guinea & 40 & 153 & 200 & 132 & $49 / 49$ & 430 & 8 & 41 & $2,040.8$ \\
\hline $\begin{array}{l}\text { Guinea } \\
\text { Bissau }\end{array}$ & - & 180 & 159 & 145 & $44 / 47$ & 140 & 2 & 39.6 & $2,945.5$ \\
\hline Liberia & - & 117 & 101 & 88 & $41 / 42$ & 130 & $\mathrm{n} / \mathrm{a}$ & $\mathrm{n} / \mathrm{a}$ & $2,213.6$ \\
\hline Mali & - & 146 & 124 & 110 & $48 / 49$ & 291 & 129 & 19 & $1,290.0$ \\
\hline Mauritania & 57 & 99 & 84 & 74 & $51 / 54$ & & & & $28,660.0$ \\
\hline Niger & $52 / 66$ & - & - & - & $46 / 46$ & 200 & 31 & 17.1 & 267.3 \\
\hline Nigeria & $32 / 50$ & 87 & 68 & 60 & $51 / 52$ & 320 & 1200 & 66.8 & $3,256.8$ \\
\hline $\begin{array}{l}\text { Sao Tome } \\
\text { and Principe }\end{array}$ & - & 189 & 195 & 160 & $67 / 73$ & & & & $1,163.8$ \\
\hline Senegal & - & 105 & 91 & 83 & $51 / 55$ & 550 & 78 & 39.3 & $1,295.1$ \\
\hline Sierra Leone & $53 / 76$ & & & & $33 / 35$ & 150 & 8 & 36 & \\
\hline Togo & 32 & 98 & 81 & 70 & $48 / 51$ & 310 & 20 & 59.6 & $1,295.1$ \\
\hline
\end{tabular}

Sources: UN (2002 and 2004); World Bank (2001) World Development Indicators; African Development Bank (1999) African Development Report 1999. OUP.

Most of the urban population in these countries is in the capital cities and a greater part of the country is rural countryside normally virtually inaccessible, with the barest forms of infrastructure or services and therefore sparsely populated. In fact in Liberia, Guinea Bissau and Sao Tome only their capital cities have populations of over 50,000. With foreign 
direct investment (FDI) of less than USD 50million respectively and GDP of less than USD 300 they are very vulnerable.

\section{Policy implications.}

It is evident that there has been a lot of policy failures within each of the countries within the region. For instance, according to UNDIESA (1981) policies to slow down rural-urban migration have been less successful due to the following reasons:

1. Weak government developmental policies (e.g. much voluntarism, but little compliance enforcement);

2. Failure of governments to perceive a conflict between excessive urban growth and national development;

3. Reliance on indirect measures of control with little effort to evaluate or coordinate their efforts on urbanisation and migration processes;

4. Emphasis on non-economic policy levers (housing and services) rather than stronger economic policy levers (jobs and prices) or on factors influencing the salience of economic factors information and accessibility;

5. Lack of coordination between rural and urban development strategies, particularly on control of a specific migration pattern at different levels of the administrative hierarchy.

Policies that would obviate imbalances in the urban growth processes of the region can be redressed with the following strategies. These must be country specific to reflect salient and individual peculiarities.

a) Each country (particularly those that have primate cities) should put in place a programme to revitalise and sustain secondary cities to reduce the pressure on the national capital.

b) As a major effort towards enhanced sanitation, there should be within each country government sponsored community based refuse disposal programmes.

c) Unavailable land is a major draw back in sustainable urban housing. Adequate housing will only be possible through the strengthening of mortgage institutions that would be driven by the urban communities, while government makes land available.

d) Transportation;

e) Poverty alleviation;

f) Good governance.

Johnson (1970) has proved with historical evidence from England, Japan, Belgium and the USA that regional development requires 'agrarian 
commercialisation' which in turn requires the creation of a network of small market towns with the spatial sphere of the nations.

\section{Conclusion}

The development of towns and cities in the national urban systems of West Africa as elsewhere deserves greater study and attention as many more people cluster into them. Even though they are centres of economic growth and provide the synergy for further regional development, the development is disproportional and dysfunctional.

The West African scenario indicates that the allure of urban centres and their growth will intensify in the next few years through self-propulsion cum economic impulses and through political and administrative changes. Governmental and proactive policy response needs to be fast and appropriate for sustainable livelihoods and a healthy urban environment.

A major area of concern remains the deplorable state of infrastructure and services in most of the urban centres of the sub-region, and the concomitant admixture of complexities and weaknesses of the political, social and economic sectors. Good governance and pro-poor policies would in the long term alleviate the extant urban poverty that remains a hydraheaded monster, and capacity needs to be enhanced both in the private sector, among CBOs, NGOs and within governmental institutions alike.

National urban development policies and strategies must tilt towards checking unrestrained urban growth of primate city systems in order to achieve a preponderance of medium-sized or secondary city systems through deconcentration and decentralization.

\section{References}

Adepoju, A. (1988) "Migration and urbanisation in Africa: Issues and Policies." In Vande Walle et al (eds.) The State of African Demography. London, IUSSP.

Aldrich, B.C. and Ravinder, S.S. (eds) (1995). Housing the Urban Poor in Developing Countries. London, Zed Books.

Amis, P. (1995) "Making Sense of Urban Poverty" Environment and Urbanisation, Vol.7, No.1 pp.145-157.

Amis, P and Rakodi, C. (1995) "Urban Poverty: Concepts, Characteristics and Policies." Habitat International, Vol.19, No.4, pp.

Amis, P and Lloyd, P. (1990). Housing Africa's Urban Poor. Manchester, Manchester University Press.

Aniah, E.J. (2004) "Secondary-cities in Sub-Saharan African Urbanisation: Challenges for Poverty Alleviation and Sustainable Livelihoods." 2004 Fellowship Lecture, Trevelyan College, University of Durham. 
Aniah, E. J. (2003) "Population censuses in Nigeria: Pitfalls and Highpoints." Nigerian Journal of Social Development Issues, Vol.3, No.1 pp.37-46.

Aniah, E. J. (2000) "The role of secondary cities in regional economic development in Nigeria." Journal of Environmental Sciences, Vol.4, no. 1 pp.31-47.

Aniah, E. J -(1997) "At the crossroads: Urban-ward migration and sustainable rural development in south eastern Nigeria." Classical Journal of Research in Education, Vol.2, No.1 pp.108-119.

Aniah, E. J and Okpiliya, F.I. (2003). Paradigms in Population, Resources and Environment: A Developmental Perspective. Calabar, Success Press.

Atlas of Africa (2004). Jaguar.

Baker, J. (ed) (1990). Small town Africa: Studies in Rural-Urban Interaction. The Scandinavian Institute of African Studies, Uppsala.

Bray, M; Clarke, P.B and Stephens, D. (1986). Education and Society in Africa. London, Edward Arnold.

Bradshaw, Y. (1985) "Over-urbanization and underdevelopment in Black Africa: A Cross National Study." Studies in Comparative International Development, Vol 1 43-56.

Brinkhoff, T. (2004) www. City Population.

Brokerhoff, M and Brennan, E. (1998). "The Poverty of Cities in Developing Regions" Population and Development Review, Vol.24 No.1 pp.75-114.

Chadivick, G. (1987), Models of Urban and regional Systems in developing Countries: Their Theories and their application in Physical Planning. Pergomon

Chant, S. (1992). Gender and Migration in Developing Countries. London, Belhaven Press.

Cooper, F. (2001). "What is the Concept of Globalization Good for? An African Historian's Perspective." African Affairs, 100(399): 189-213.

Corbridge, S. (1995) Development Studies: A Reader. London, Edward Arnold.

Cowen, M and Shenton, R. (1996). Doctrines of Development. London, Routledge.

Devas, N. and Rakodi, C. (eds) (1993). Managing Fast Growing Cities: New Approaches to Urban Planning and Management in the Developing World. Harlow, Longman.

Devas, N. and Korboe, D. (2000). "City Governance and Poverty: The Case of Kumasi." Environment and Urbanisation, Vol 12, No.1 pp.123-135.

Dickenson, J.P. et al (1996). A Geography of the Third World. $2^{\text {nd }}$ Edition, London, Routledge. 
Doan, P.L. (1998). "Institutionalizing Household waste Collection: The Urban Environmental Management Project in Cote d' Ivoire" Habitat International, Vol.22, No.1 pp.49-56.

Drakakis-Smith, D. (1995). "Third World Cities: Sustainable Development I" Urban Studies, Vol. 32 (4-5) pp. 659-677.

Drakakis-Smith, D. (1996). "Third World Cities: Sustainable Development II- Population, Labour and Poverty" Urban Studies, Vol.33 pp.673-701. Egunjobi, L (1990). "The Development Potentials of Local central Places in Nigeria". In Baker, J. (ed). Small Town Africa: Studies in Rural-Urban Interaction,.69-88.

Elliot, J. (1994). Sustainable Development. London, Routledge.

Encyclopedia of Africa South of the Sahara (1997). New York, Charles Scribners \& Sons. Vols. 1-4.

Escobar, A. (1995). Encountering Development: The Making of and Unmaking of the Third World. Princeton, Princeton University Press.

FGN (2003). National Policy on Population for Sustainable Development. National Population Commission (NPC), Abuja, Government Press.

Filani, M.O. (1981). "Nigeria: The Need to Modify Centre -Down Development Planning." In Stohr, W.B. and Taylor, D.R.F. (eds) Development from Above or Below, Chichester, John Wiley, 283-304.

Gilbert, A. (1992)."Third World Cities: Housing, Infrastructure and Servicing.” Urban Studies, Vol.29, 435-460.

Gilbert, A. (1993). "Third World Cities: The Changing National Urban Settlement System.” Urban Studies, Vol.30, pp.721-740.

Goliber, T.J. (1989). "Africa's Expanding Population: Old Problems, New policies." Population Bulletin, Vol.44 No.3 Population Reference Bureau Inc.

Gore, C. (1984). Regions in Question: Space, Development Theory and Regional Policy. London and New York, Methuen.

Gugler, J. (2002). "The son of a hawk does not remain abroad: The urbanrural connection in Africa." African Studies Review, Volume 45 (1), pp. 309-319.

Gugler, J (1997). Cities in the Developing World: Issues, Theory and Policy. New York, Oxford University Press.

Gugler, J (1996)."Urbanisation in Africa South of the Sahara: New Identities in Conflict." In Gugler, J. (1996). The Urban Transformation of the Developing World. Oxford, Oxford University Press.

Guyer, J (ed) (1987). Feeding Africa's Cities: Readings in Regional Social History. Manchester, Manchester University Press.

Hardoy, J; Mitlin, D. and Satterthwaite, D. (2001). Environmental Problems in an Urbanizing World: Finding Solutions for Cities in Africa, Asia and Latin America. London, Earthscan Publications Ltd. 
Hope, Sr. K.R. (1999). "Managing Rapid Urbanisation in Africa: Some Aspects of Policy." Journal of Third World Studies, Vol.16, No.2 pp.47-59.

Hope, Sr. K.R and Lekorwe, M.H. (1999). "Urbanisation and the Environment in Southern Africa: Towards a Managed Framework for the Sustainability of Cities." Journal of Environmental Planning and Management, Vol.42, No.6, pp.837-859.

Johnson, E.A.J. (1970). The Organisation of Space in Developing Countries. Cambridge, Massachusetts, Harvard University Press.

Kamete, A.Y; Tostensen, A. and Tvedten, I. (2001). "From Global Village to Urban Globe: Urbanisation and Poverty in Africa: Implications for Norwegian Aid Policy." Chr. Michelsen Institute Report, 2, pp.1-95.

Karekezi, S; and Majoro, L (2002). "Improving Modern Energy Services for Africa's Urban Poor." Energy Policy, Vol.30 Nos 11/12, pp.10151028.

Kasarda, J.D. and Parnell, A.M. (Eds.) (1996). Third World Cities: Problems, Politics and Prospects. London, Sage.

Lipton, M. (1977). Why Poor People Stay Poor: The Urban Bias in World Development. Cambridge, MA; Harvard University Press.

Lipton, M. (1982) "Family, fungibility and formality: Rural advantages of informal non-farm enterprises versus the urban-formal state". In Amin $\mathrm{S}$ (Ed) Human Resources, employment and development. Vol 5 London, Macmillan.

Mabogunje, A.L. (1990). "The Organisation of Urban Communities in Nigeria." International Social Science Journal, Vol.42, No.125, pp.355-366.

Mabogunje, A.L. (1989). The Development Process: A Spatial Perspective. $2^{\text {nd }}$ edition, London, Unwin Hyman.

Mabogunje, A.L (1991) "A new Paradigm for urban development strategy in developing countries". Paper presented at the World Bank annual Conference on development. 25/26 April, Washington DC.

Mabogunje, A.L -(1970) "Systems approach to a theory of rural-urban migration." Geographical Analysis. Vol. 2 No. 8 pp. $1-18$.

National Population Commission (NPC) (2000). Nigeria Demographic and Health Survey 1999, Abuja, NPC.

Njoh, A.J. (2003). "Urbanisation and Development in Sub-Saharan Africa." CITIES, Vol.20, No.3, pp.167-174.

Peil, M. (1991), Lagos: The City is the People. World city series. Belhaven press London.

Peil, M. (1984) "African Urbanization in Comparative Perspective" Inaugural Lecture, University of Birmingham.

Peil, M. (1981). Cities and Suburbs: Urban Life in West Africa. Africana Publishing. 
Peil, M. and P.O. Sada (1984). African Urban Society. Chichester, John Wiley and Sons.

Polese, M. (1997). "Urbanisation and Development (Canadian International Development Agency (CIDA)". Development Express 4, pp.4-8.

Potter, R.B. and Lloyd-Evans. (1998). The City in the Developing World. Essex, Longman.

Pugh, C. (1995). "Urbanisation in Developing Countries: An Overview of the Economic and policy Issues in the 1990s." CITIES, Vol.6, pp.381398.

Pugh, C (ed) (1996) Sustainability, the Environment and Urbanisation. London, Earthscan.

Reed, D. and Herman, R. (1999). Globalization, Poverty and the Environment. WWF-MPO, Washington, D.C.

Renaud, B. (1981).National Urbanisation Policy in Developing Countries. Oxford, Oxford University Press.

Roberts, B. (1978), Cities of Peasants: Explorations in Urban Analysis. London, Edward Arnold.

Roberts, B. (1995), Market and States in Tropical Africa, Berkeley, University of California Press

Rondinelli, D.A. (1983). Secondary Cities in Developing Countries: Policies for Diffusing Urbanisation. London, Sage Publications.

Satterthwaite, D. (1997). "Sustainable Cities or Cities that Contribute to Sustainable Development." Urban Studies, Vol.34, No.10 pp.16671697.

Sikod, F. (2001). "Constraints to Managing Urban Poverty in Cameroon." Environment and Urbanisation, Vol.13, No.1 pp.201-208.

Simon, D. (1992). Cities, Capital and Development: African Cities in the World Economy. London, Belhaven.

Simon, D -(1996). Transport and Development in the Third World. London, Routledge.

Simon, D -(2001). "Dilemmas of Development and Environment in a Globalizing World: Theory, Policy and Praxis". Inaugural Lecture, Royal Holloway, University of London.

Simon, D, McGregor D. and Nsiah-Gyabaah, K. (2004). "The Changing Urban-Rural Interface of African Cities: Definitional Issues and an Application to Kumasi, Ghana." Environment and Urbanisation, Vol. 16, No. 2 pp.235-247.

Simone, A. (2003). "Reaching the Larger World: New Forms of Social Collaboration in Pikine, Senegal." AFRICA, Vol. 73, No.2 pp.226-250.

Smith, D. J. (2004). "Contradictions in Nigeria's Fertility Transition: The Burdens and Benefits of Having People." Population and Development Review, Volume 30 (2), pp.221-238. 
Stren, R, White, R and Whitney, J. (eds) (1992). Sustainable Cities:

Urbanisation and the Environment in International Perspective, Boulder, CO: Westview Press.

Todaro, M. P. (1986), Economic Development in the third world. $4^{\text {th }}$ Edition Longman. The Africa Report (2005). (Jeune Afrique), $1^{\text {st }}$ Edition.

United Nations Population Division, (2003). World Population Prospects:

The 2002 Revision. New York, United Nations.

United Nations (1991). World Population Prospects. New York, United Nations, UNCHS, 1996.

United Nations Development Programme (UNDP), (2000). Human Development Report, Oxford and New York, Oxford Development Report.

UNDP (2001) Human Development Report 2001: Making New

Technologies Work for Human Development. New York, Oxford University Press.

Van de Walle, Etienne and Andrew Foster, (1990). "Fertility Decline in Africa: Assessment and Prospects" World Bank Technical Report, Washington DC.

Wisner, B. (1988). Power and Need in Africa. London, Earthscan.

World Bank (1998). World Development Report, The World Bank, Washington, DC.

World Bank (2002). 2001 World Development Indicators. The World Bank, Washington DC.

Wolfe, M. (1996). Elusive Development. London, Zed. 